Vol. 3, No. 2, Juli 2019, 41-50

Available Online at https://ejournal.warmadewa.ac.id/index.php/kulturistik DOI: dx.doi.org/10.22225/kulturistik.3.2.1192

\title{
LEKSIKON-LEKSIKON FLORA DALAM METAFORA BAHASA BALI: KAJIAN EKOLINGUISTIK
}

\author{
I Made Astu Mahayana \\ Universitas Warmadewa \\ astumahayana@gmail.com \\ Ni Ketut Sukiani \\ Universitas Warmadewa \\ ketutsukiani@gmail.com \\ Ni Made Suwendri \\ Universitas Warmadewa \\ suwendri63@gmail.com \\ Made Detrichyeni Winaya \\ Universitas Warmadewa \\ made.detrichyeni.winaya@gmail.com
}

\begin{abstract}
ABSTRAK
Penelitian ini mengkaji tentang metafora yang berkaitan dengan lingkungan alam, yaitu flora yang hidup di Bali. Tujuan penelitian ini adalah: pertama menemukan dan menganalisis leksikon-leksikon flora dalam metafora bahasa Bali. Kedua, menganalisis dan mendeskripsikan makna metaforis secara kognitif antara ranah sumber dan ranah target, dan ketiga menganalisis dan menjelaskan bagaimana metafora tersebut terbentuk dalam dimensi praksis sosial atau dimensi logis. Metode yang digunakan dalam penelitian ini adalah metode deskriptif kualitatif. Data tulis berasal dari beberapa sumber, seperti buku Basita Parihasa (buku yang mengkoleksi kata-kata, sindiran, metafora, dan kiasan lainnya dalam bahasa Bali) dan buku cerita pendek, serta lirik lagu dalam bahasa Bali sebagai data pustaka. Data tambahan berupa data lisan yang berasal dari penutur asli bahasa Bali. Makna metaforis yang ditemukan dalam penelitian inimenggambarkan kesamaan ciri, yang berupa bentuk tubuh, sifat, dan keadaan manusia. Dengan kata lain, proses kognitif yang terjadi dalam menghasilkan ungkapan metaforis, yaitu dengan mengonseptualisasikan pengalaman yang dirasakan oleh tubuh, sifat, dan ciri, yang dimiliki sumber dengan yang dimiliki target. Pembentukan metafora terjadi oleh adanya proses pemetaan silang melalui parameter ekolinguistik, karena adanya kedekatan ciri atau karakter biologis yang dimiliki oleh ranah sumber dan ranah target, khususnya antara masyarakat Bali dengan lingkungan alam (flora yang hidup di Bali) yang kemudian terekam secara verbal yang seterusnya terpola dalam tataran dimensi praksis sosial.
\end{abstract}

Kata kunci: ekolinguistik, leksikon flora, metafora bahasa Bali, dimensi logis.

\begin{abstract}
[Title: Lexicons of Flora in Balinese Metaphors: Ecolinguistic Studies]This research is an ecolinguistic study focused on metaphors that is related to ecological environment that concerns flora. The reseacrch is firstly aimed at finding and analyzing the lexicons of flora found in Balinese metaphors. Secondly, it is aimed at analyzing and describing
\end{abstract}


Vol. 3, No. 2, Juli 2019, 42

Available Online at https://ejournal.warmadewa.ac.id/index.php/kulturistik DOI: dx.doi.org/10.22225/kulturistik.3.2.1192

cognitive metaphorical meaning between the source and target, and thirdly is aimed at analyzing and describing how the metaphors and metaphorical expressions were constructed. The method used in this research was descriptive qualitative method. The written data were collected from some sources, like Basita Parihasa (book collection of words, sarcasms, metaphors, and others in Balinese), a short story of Balinese containing metaphorical expressions and a Balinese song lyric. The spoken data were collected from an informan as a native speaker of Balinese language.Based on the analysis results, The metaphorical meanings found in this writing mostly showed the similarity, such as body shape, characteristic, situation, and conditon of a human. In other words, cognitive process occured by conceptualizing bodily experience by similarity of the source and target domain in processing metaphorical expressions. It is also found that the Balinese metaphors were constructed by mapping process through ecolinguistic parameters. The mapping process occured, due to the similarity of character or system between source and target, especially Balinese people and ecological environment (flora which exist in Bali). The metaphors were also constructed by bodily experience of the language users which were recorded in human's cognitive under the praxis social dimension.

Keywords: flora lexicons, balinese metaphors, logical dimension.

\section{PENDAHULUAN}

Pulau Bali atau yang juga dikenal dengan sebutan Pulau Dewata, memiliki pesona keindahan dan kekayaan budayaan yang masih sangat kental melekat pada penduduknya. Di era globalisasi ini, kondisi alam di Bali kian lama kian menyusut. Ketidakharmonisan antara manusia dan alam menjadi penyebab menyusutnya kondisi alam tersebut. Dengan dalih kepentingan pembangunan, manusia melakukan eksploitasi alam tanpa memikirkan efek jangka panjang yang akan ditimbulkan (Suweta, 2013). Masyarakat seharusnya menanggapi hal ini dengan sungguh-sungguh, karena bukan hanya berdampak pada lingkungan, namun berdampak pula pada kepunahan leksikal. Kepunahan leksikal yang berkepanjangan akan memunculkan kepunahan bahasa (Rasna, 2012). Untuk melestarikan leksikon-leksikon tersebut, masyarakat menggunakannya dalam bahasa -bahasa kiasan seperti salah satunya pada beblabadan (Rajistha, 2016).

Masyarakat Bali adalah masyarakat yang sangat memiliki ketergantungan dengan alam, seperti halnya dalam keperluan upacara adat, obat-obatan, bahan pangan, dll. Dalam upacara adat misalnya, dalam suatu upacara mecaru diperlukan siap selem 'ayam hitam' untuk sebuah sesaji dalam ritual upacara yang diyakini masyarakat Hindu di Bali. Dalam pengobatan alternatif, masyrakat Bali (khususnya yang hidup di pedesaan) menggunakan don kayu manis untuk menghilangkan panas dalam.Selain itu, masih banyak lagi fenomena masyarakat Bali lainnya yang berhubungan dengan ketergantungan alam, khususnya ketergantungan masyarakat Bali terhadap flora dan fauna.

Mencintai dan merawat lingkungan, serta hidup berdampingan secara harmonis dengan alam dan sesama makhluk hidup lainnya adalah suatu refleksi di mana bahasa itu hidup dan berkembang. Refleksi lainnya tampak pula pada gayagaya bahasa yang bertujuan memiliki kesan imajinatif dalam komunikasi yang disebut dengan majas. Menurut Moeliono, majas digunakan untuk mengonkretkan dan menghidupkan sebuah tulisan sehingga tulisan tersebut tidak bersifat monoton dan lebih variatif (Moeliono, 1989). Salah satu majas yang paling sering digunakan dalam karya seni dan kehidupan masyarakat adalah metafora. Lakoff dan Johnson menyatakan bahwa metafora ada di dalam kehidupan sehari-hari, 
Vol. 3, No. 2, Juli 2019, 43

Available Online at https://ejournal.warmadewa.ac.id/index.php/kulturistik DOI: dx.doi.org/10.22225/kulturistik.3.2.1192

dan tidak hanya di dalam kegiatan berbahasa, tetapi tersusun di dalam pikiran dan tindakan manusia (Lakoff \& Johnson, 1980), hal tersebut direfleksikan dalam kehidupan bermasyarakat di Bali, seperti contoh: 'dueg gati ngalap pitresnan anak'. Ungkapan tersebut dialamatkan kepada seseorang yang pandai bergaul dan mengambil hati seseorang. Kata 'ngalap' memetik dalam ungkapan tersebut berkaitan dengan entitas flora, yang mana kata 'ngalap' merupakan aktivitas memetik/memanen/mengambil sesuatu atau entitas konkret seperti ngalap poh 'memetik mangga', ngalap jepun 'memetik bunga kamboja' dan ngalap yang diikuti oleh entitas konkret flora lainnya. Bentuk ungkapan dalam contoh tersebut diatas merupakan fenomena yang terjadi dalam interaksi keseharian masyarakat tutur bahasa Bali dalam kehidupan sosial.

\section{METODE}

Penelitian ini berfokus kepada leksikon flora yang tertuang dalam makna metaforis antara ranah sumber dan ranah target yang terkandung dalam ungkapan metafora bahasa Bali. Sumber data dalam penelitian ini adalah buku Basita Parihasa yang disusun oleh Simpen (1993) dan cerita pendek bahasa Bali oleh Sewamara (1977), serta beberapa lirik lagu bahasa Bali yang diidentifikasi mengandung ungkapan dan makna metaforis. Sumber data tersebut dipilih karena terdapat banyak kalimat dan ungkapan metaforis bahasa Bali yang berhubungan antara manusia dengan flora sebagai ranah sumber dan ranah target. Selain itu, Penelitian ini adalah penelitian kualitatif yang melibatkan langsung peneliti yang secara subjektif berperan sebagai alat utama penjaring data (human instrument) dalam sejumlah peristiwa budaya dengan tetap berupaya menjaga dan membangun objektivitas penelitian (Mbete, 2006).

Penelitian ini tidak bersifat lapangan, melainkan pada buku-buku atau karya tulis. Penelitian ini menggunakan peneliti sebagai instrumen utama, yang merupakan perencana, pelaksana, pengumpul data dan informasi, analisis, dan penafsir data. Menurut Deignan (Deignan, 2005), metode intuitif sering digunakan para peneliti metafora konseptual, seperti Lakoff dan Johnson, Kovecses, yaitu dengan menggunakan pengalaman peneliti yang telah menginternalisir di dalam diri peneliti.

Metode pengumpulan data yang digunakan dalam penelitian ini adalah studi kepustakaan, yaitu pengumpulan data dengan mengadakan studi penelaahan terhadap buku-buku, litertur-literatur, catatan-catatan, dan laporan-laporan yang ada hubungannya dengan masalah yang dipecahkan (Nazir, 1988). Dalam tahap analisis data, metode yang digunakan dalam penelitian ini adalah deskriptifanalitik. Metode ini mendeskripsikan data untuk menemukan unsur-unsur data tersebut yang dilanjutkan dengan analisis dan didukung dengan teknik catat. Data yang ditemukan kemudian dideskripsikan dan dianalisis dengan menggunakan teori dimensi logis ekolinguistik untuk mengungkap makna metaforis yang terkandung dalam kalimat metafora yang kemudian diklasifikasikan ke dalam klasifikasi flora.

\section{PEMBAHASAN}

Tanaman atau tumbuh-tumbuhan (flora) yang hidup di Bali tentunya memiliki keunikan dan manfaat bagi masyarakat Bali. Dalam sub bab ini akan dipaparkan data-data yang berupa leksikon tanaman atau tumbuh-tumbuhan yang pernah tumbuh dan yang masih tumbuh hingga saat ini.Ungkapan metaforis 
Vol. 3, No. 2, Juli 2019, 44

Available Online at https://ejournal.warmadewa.ac.id/index.php/kulturistik DOI: dx.doi.org/10.22225/kulturistik.3.2.1192

adalah ungkapan yang menunjukkan konseptualisasi dan mengindikasikan pemaha-man atas suatu konsep dengan konsep lain (Nirmala, 2012). Berikut adalah data yang ditemukan dalam penelitian.

\section{Beling Padi}

Beling padi 'padi yang berisi' secara linguistik adalah frasa yang termasuk dalam kategori nomina yang merujuk kepada tumbuhan padi (Oryza sativa) yang biasanya dapat ditemui di sawah. Beling padi dalam bahasa Bali merujuk kepada padi yang sudah siap untuk dipanen. Padi yang siap dipanen dalam tatanan $d i$ mensi biologis diidentifikasi memiliki warna yang mulai menguning dan tunduknya tangkai yang disebabkan oleh serat yang menanggung butir-butir padi yang bertambah berat. Pada musim kemarau, padi biasanya dapat dipanen lebih awal. Secara umum padi dapat dipanen pada umur antara 110-115 hari setelah tanam. Perkembangan biologis padi dalam kehidupan sosial dipahami dalam kognitif dan melalui pengalaman inderawi oleh masyarakat Bali (dimensi ideologis). Melalui pengalaman inderawi tersebut masyarakat memahami bentuk padi yang berisi atau siap panen.

Tanaman padi dan masyarakat Bali memiliki relasi yang sangat dekat, khususnya para petani yang dapat dilihat dari banyaknya jumlah padi yang ditanam. Dari relasi tersebut terbentuklah sebuah metafora MELING PADI seperti tuturan berikut ini:

\section{BETEKAN BATISNE MELING PADI (Simpen, 1993: 47) \\ 'Betisnya berisi padi'}

Makna metaforis BETEKAN BATISNE MELING PADI dialamatkan kepada orang yang memiliki bentuk betis besar seperti padi yang berisi. Kata meling berasal dari kata beling yang diklasikasikan sebagai nomina kompleks yang mendapat anusuara atau simulfiks $m$-, sehingga mengubah kelas kata menjadi verba meling. Beling padi dipahami sebagai tumbuhan padi yang padat dan berisi atau dalam bahasa Bali disebut jelih (dimensi sosiologis).

Secara struktural beling padi merujuk kepada betekan batis karena memiliki kemiripan ciri yang dapat dibuktikan secara visual, sehingga dapat dipahami sebagai betis kaki yang besar, sedikit bergaris, dan berwarna agak kuning layaknya padi yang siap panen. Jadi, ranah sumber pada kalimat di atas adalah $B E L-$ $I N G P A D I$, dan ranah sasarannya secara implisit mengacu pada BETEKAN BATIS. Metafora pada kalimat tersebut di atas mengacu pada konsep BETEKAN $B A T I S$ yang dijelaskan melalui bentuk, tekstur, dan ciri yang dimiliki oleh $B E L$ ING PADI

\section{Sandat Gading (Cananga Odorayum Baill)}

Sandat gading 'bunga kenanga kuning' secara linguistik merupakan frasa nomina dalam bahasa Bali yang merupakan jenis bunga layu berwarna kekuningan dari tanaman bunga kenanga. Relasi bunga sandat dengan masyarakat tutur bahasa Bali dalam kehidupan sosial sangat dekat. Kedekatan hubungan tersebut dapat dilihat dari banyaknya bunga yang ditanam oleh masyarakat Bali karena aroma wanginya dan bernilai ekonomis.

Secara alami bunga ini hijau kekuningan dengan lima hingga enam mahkota yang panjang dan berbentuk spiral tidak beraturan. Jika berwarna kuning, be- 
Vol. 3, No. 2, Juli 2019, 45

Available Online at https://ejournal.warmadewa.ac.id/index.php/kulturistik DOI: dx.doi.org/10.22225/kulturistik.3.2.1192

rarti bunga tersebut sudah mulai tua dan layu. Semakin layu, maka semakin harumlah bunga ini (dimensi biologis). Oleh masyarakat Bali disebut dengan sandat gading. Dalam upacara ritual agama Hindu di Bali, bunga sandat sering dijumpai. Bunga ini biasanya digunakan sebagai sarana ritual dalam persembahyangan. Karakter biologis bunga sandat terekam secara verbal dalam mental dan kognitif (dimensi ideologis) masyarakat yang selanjutnya membentuk metafora NYANDAT GADING. Dalam guyub tutur masyarakat bahasa Bali, ungkapan NYANDAT GADING biasanya dianalogikan dengan PAMULU 'KULIT', yang secara struktural diidentifikasi memiliki kemiripan struktur antara bunga sandat gading dan warna kulit manusia (umumnya gadis).

Dalam metafora tesebut, kata nyandat berasal dari kata sandat yang mendapat simulfiks ny-, sehingga merubah kata nomina menjadi verba. Makna metaforis yang terdapat pada PAMULUNE NYANDAT GADING (Simpen, 1993: 48) pada umumnya dialamatkan kepada gadis berparas ayu yang memiliki warna kulit yang bersih dan berwarna kuning langsat. Karena keberadaan, bentuk, ciri khas dan kemanfaatannya, bunga sandat merupakan ranah sumber yang dipetakan kepada pamulu 'kulit' sebagai ranah target (dimensi sosiologis) dalam mental kognitif masyarakat tutur pada tataran dimensi ideologis.

\section{Ngalap}

Ngalap 'memetik' merupakan kata yang termasuk klasifikasi verba yang tergolong leksikon bentuk turunan. Ngalap berasal dari kata alap yang mendapat simulfiks ng- yang membentuk kata kerja dalam cakapan bahasa Bali. Kata ngalap merujuk ke aktivitas mengambil hasil panen dari tumbuhan di atas tanah, khususnya pohon, khususnya dalam lingkungan guyub tutur petani dan masyarakat Bali yang berkebun pada umumnya, seperti contoh: ngalap bunga, ngalap nyuh, dan lainnya.

Dalam tatanan dimensi sosiologis, kata ngalap masih sering digunakan dalam komunikasi bahasa Bali, baik orang tua maupun anak muda. Oleh karena itu hubungan atau keterkaitan (interelationship) aktivitas ini dengan masyarakat Bali memiliki hubungan yang sangat erat. Eratnya relasi kata ngalap ini dapat dilihat dari masih adanya suatu aktivitas memetik/memanen dalam suatu lingkungan, walaupun kian lama berkurang mengingat tingginya angka eksploitasi alam yang terjadi di Bali.

Pada umumnya masyarakat merekam konsep ngalap 'memetik' dalam mental dan kognitif masyarakat tutur dalam tatanan dimensi ideologis sebagai makna positif karena memetik diartikan suatu aktivitas yang membawa manfaat. Hasil petikan (buahnya) bermanfaat bagi masyarakat karena buahnya bisa dimakan atau dijual. Selain itu dalam memetik/memanen sesuatu diperlukan keterampilan untuk memilih hasil yang ingin dipetik. Seperti contoh ngalap poh 'memetik mangga'. Sebelum memilih mangga yang tasak 'matang' seseorang wajib mengetahui buah tersebut dari warna atau bentuknya. Pemahaman konsep ngalap tersebut kemudian membentuk metafora dalam tuturan lazim yang sering dituturkan seperti berikut:

'Dueg pisan masawitra, turing NGALAP PITRESNAN ANAK' (Sewamara, 1977: 2)

'Pintar sekali bergaul dan mengambil hati orang 
Vol. 3, No. 2, Juli 2019, 46

Available Online at https://ejournal.warmadewa.ac.id/index.php/kulturistik DOI: dx.doi.org/10.22225/kulturistik.3.2.1192

Ungkapan di atas tersebut memiliki makna metaforis yang dialamatkan kepada orang yang baik hati dan mampu membuat orang lain kagum kepadanya. Jenis metafora ini adalah metafora ontologis yang menggambarkan fenomena non fisik yang konkret, yang diidentifikasi pada kata NGALAP 'MEMETIK'yang disandingkan dengan PITRESNAN ANAK 'HATI ORANG'.Ungkapan dalam data (3) merupakan metaforis karena kata ngalap disandingkan dengan pitresnan anak. Apabila kata ngalap disandingkan dengan poh 'mangga' atau sekar 'bunga', maka ungkapan tersebut tidak metaforis karena kedua entitas tersebut merupakan entitas konkret. Hal ini dapat divisualisasikan atau dilihat bagaimana seseorang dapat memanen buah atau bunga yang merupakan entitas konkret. Ungkapan pada data ini mengindikasikan adanya metafora + PITRESNAN ANAK 'HATI ORANG' ADALAH HASIL PANEN+. Kata ngalap dalam ungkapan ini mengandung fitur semantis 'mengambil hati'. Metafora ngalap pitresnan anak mengandung verba ngalap yang memiliki muatan tambahan sikap penutur yang ingin menunjukkan bagaimana terampilnya seseorang dalam memikat hati orang lain.

\section{Papah Biu}

Ditinjau dari segi bentuk dan kategorinya, Papah biu 'pelepah pohon pisang' secara linguistik termasuk dalam klasifikasi nomina dan merupakan leksikon bentuk turunan yang berupa frasa, yang merujuk kepada nama bagian batang tanaman don biu 'pohon pisang' (Musa Paradisiaca, Linn.). Papah biu merupakan bagian terluar dari don biu yang berfungsi untuk melindungi bagian dalam tubuh pisang.

Keberadaandon biu di Bali masih banyak bisa ditemui, terutama di wilayah pedesaan bagian timur. Parameter kesalingtergantungan (interdependensi) antara manusia dan don biu sangat mendalam.Dapat dilihat dari banyaknya don biu yang ada di Bali yang keberadaanya memberikan manfaat bagi kehidupan sosial masyarakat dan bernilai ekonomis (dimensi biologis). Selain buahnya yang mengandung khasiat dan protein yang tinggi, banyak bagian dari tanaman ini yang bermanfaat. Salah satunya adalah papah 'pelepah'nya yang bisa dimanfaatkan untuk kerajinan tangan.

Bentukpapah biu yang ada pada don biu berbentuk melengkung menyerupai kuku panjang yang dimiliki manusia. Pemahaman karakter biologis $p a-$ pah biu terekam dalam kognitif masyarakat Bali dalam tatanan dimensi ideologis dan terbentuklah metafora MAPAH BIU. Contoh tuturan dengan PAPAH BIU yang lazim diungkapkan oleh masyarakat guyub tutur bahasa Bali adalah seperti berikut:

KUKUNE MEMAPAH BIU (Simpen, 1993: 47)

'kukunya berbentuk seperti pelapah pisang'

Keterkaitan antara bentuk $k u k u$ dan bentuk papah biu membentuk metafora KUKUNE MEMAPAH BIU. Sebagaimana tampak pada gambar di atas, makna metaforis yang terkandung dalam ungkapan tersebut dialamatkan kepada seseorang yang memiliki kuku panjang dan melengkung. Dalam kehidupan sosial masyarakat Bali pada dimensi sosiologis, tujuan sebagian orang memanjangkan kuku adalah sebagai seni, khususnya seni tari. Para seniman memanjangkan kuku mereka agar saat merka menari, mereka dapat memancarkan keindahan dalam 
Vol. 3, No. 2, Juli 2019, 47

Available Online at https://ejournal.warmadewa.ac.id/index.php/kulturistik DOI: dx.doi.org/10.22225/kulturistik.3.2.1192

ngejerin lima'menggerakan jari', khususnya dalam tari topeng.

MetaforaKUKUNE MEMAPAH BIU merupakan struktur kalimat yang berasal dari penyandingan $K U K U$ dengan PAPAH BIU. Kata memapah berasal dari kata papah yang diklasifikasikan sebagai kata nomina yang kemudian mendapat imbuhan me- yang mengubah kelas kata menjadi verba (memapah). Jika dilihat dari ranah target dan ranah sumber, ranah sumber pada kalimat di atas adalah $P A$ $P A H B I U$, dan ranah sasarannya secara implisit mengacu pada $K U K U$. Metafora pada kalimat tersebut di atas mengacu pada konsep $K U K U$ yang dijelaskan melalui bentuk, tekstur, dan ciri yang dimiliki oleh $P A P A H B I U$.

\section{Pudak Sinungsang (Kevda pandanaceae)}

Secara linguistik,pudak sinungsang atau pudak sungsang 'pudak yang terbalik' merupakan frasa yang termasuk dalam kelompok nomina yang merujuk kepada bunga dari tanaman bungan pudak 'bunga pudak'. Eratnya relasi tanaman ini dengan masyarakat terlihat dari banyaknya jumlah bungan pudak yang ditanam oleh masyarakat Bali (khususnya perkebunan di wilayah pedesaan) yang memiliki banyak manfaat dan bernilai ekonomis. Bunga ini berwarna putih kekuningan dengan panjang sekitar $20 \mathrm{~cm}$. Layaknya padi, bunga ini tumbuh menghadap ke bawah karena berat bunga tersebut melebihi berat dahannya, sehingga dahannya tidak sanggup menopangnya ke atas (dimensi biologis).

Dalam tatanan dimensi sosiologis, bunga ini biasanya sering digunakan dalam sarana ritual upacara di Bali. Selain itu minyak yang terkandung dalam bunga ini bisa digunakan sebagai minyak rambut, yang berkhasiat membuat rambut menjadi lembut dan harum.

Secara alami bungan pudak mirip dengan pandan yang merupakan jenis tumbuhan monokotil yang memiliki daun beraroma yang khas. Pemahaman bentuk dan karakteristik bungan pudak terekam dalam kognitif masyarakat tutur bahasa Bali dalam tatanan dimensi ideologis. Bentuk dan karakter bungan pudak yang tumbuh menghadap bawah dan memiliki panjang hingga $20 \mathrm{~cm}$ tersebut kemudian membentuk metafora (BUNGAN) PUDAK SINUNGSANG yang lazim didengar seperti berikut:

BATISNE MUDAK SINUNGSANG (Simpen, 1993: 47)

'kakinya seperti bunga pudak yang terbalik'

Makna metaforis metafora BATISNE MUDAK SINUNGSANG dialamatkan kepada seseorang yang memiliki kaki putih, jenjang, dan bersih, khususnya kaum wanita seperti gambar di atas. Kata mudak berasal dari kata pudak yang mendapat simulfiks $\mathrm{m}$ - menjadi verba mudak. Metafora pada kalimat tersebut di atas adalah jenis metafora struktural, yang teridentifikasi terdapatnya kemiripan ciri atau sistem yang mengacu pada konsep BATIS yang dijelaskan berdasarkan pengalaman inderawi (indera penglihatan) melalui bentuk, warna, dan ciri yang dimiliki oleh BUNGAN PUDAK SINUNGSANG sebagaimana tampak pada gambar di atas. Metafora pada kalimat tersebut di atas mengacu pada konsep BATIS yang dijelaskan melalui bentuk, tekstur, dan ciri yang dimiliki oleh BUNGAN PUDAK. Ranah sumber pada kalimat di atas adalah BUNGAN PUDAK, dan ranah sasarannya secara implisit mengacu pada BATIS. 
Vol. 3, No. 2, Juli 2019, 48

Available Online at https://ejournal.warmadewa.ac.id/index.php/kulturistik

DOI: dx.doi.org/10.22225/kulturistik.3.2.1192

\section{Nyuh (Cocos nucifera)}

Nyuh 'kelapa' secara linguistik kata nyuh merupakan kata yang termasuk ke dalam kategori nomina. Nyuh merujuk kepada nama buah dari tanaman $p u-$ nyan nyuh 'pohon kelapa. Eratnya interaksi antara masyarakat dengan punyan nyuh dalam tatanan dimensi sosiologis dapat dilihat dari banyaknya pohon kelapa yang tumbuh dan keberadaanya dibudidayakan oleh masyarakat karena bernilai ekonomis. Tumbuhan ini dimanfaatkan hampir semua bagiannya oleh masyarakat Bali sehingga dianggap sebagai tumbuhan serbaguna. Nyuh adalah sebutan buah dari tumbuhan ini yang juga memiliki kekayaan manfaat, khususnya dalam kesehatan. Buah ini keras dan besar, memiliki diameter $10 \mathrm{~cm}-20 \mathrm{~cm}$, biasanya berwarna hijau atau kuning.

Kelapa berwarna kuning atau kekuningan dikenal dengan namanyuh gading. Buah ini tidak sulit untuk didapatkan, biasanya banyak ditemui di pantai dan kebun di wilayah pedesaan. Pemahaman karakter biologis buah ini melalui pengalaman masyarakat disebabkan oleh kedekatan interaksi masyarakat dengan buahnya (dimensi biologis) dan kemudian terekam dalam kognitif masyarakat tutur secara verbal (dimensi ideologis). Dari pengalaman dan pemahaman ini terbentuklah suatu simile dengan konsep nyuh gading sebagai ranah sumber seperti ungkapan lazim di bawah berikut:

SUSUNE KADI NYUH GADING KEMBAR (Simpen, 1993: 45)

'payudaranya seperti buah kelapa kuning yang kembar'

Makna metaforis dalam ungkapan simile di atas dialamatkan kepada wanita yang memiliki payudara besar dan kuning langsat sebagaimana tampak pada gambar di atas. Konsep SUSU 'PAYUDARA' yang merupakan ranah sasaran dipetasilangkan kepada konsep NYUH GADING 'KELAPA KUNING' sebagai ranah sumber. SUSU digambarkan memiliki kemiripan bentuk dan warna seperti yang dimiliki oleh NYUH GADING. Keterkaitan antara ranah sumber NYUH GADING dengan ranah target SUSU terletak pada kemiripan cirinya yang berupa bentuk. Jenis metafora pada metafora ini adalah metafora struktural, yaitu terdapat kesamaan ciri atau struktur yang dapat dibuktikan secara visual atau kasat mata berdasarkan pengalaman empiris masyarakat tutur bahasa Bali yang tersimpan dalam manah.

Selain simile nyuh gading yang memiliki makna metaforis dan merupakan bagian dari punyan nyuh, masih ada metafora lain yang merupakan unsur nyuh dalam guyub tutur bahasa Bali, yaitu sambuk 'serabut kelapa'. Keberadaannya sangat bermanfaat bagi masyarakat, biasanya digunakan sebagai pengganti kayu bakar untuk memasak (dimensi biologis). Namun sambuk kini sudah jarang digunakan oleh masyarakat, mengingat kemajuan teknologi di jaman globalisasi, di mana masyarakat sudah beralih menggunakan kompor dalam kebutuhan memasak setiap hari. Kendati demikian, interaksi, interrelasi, dan interdependensi sambuk dengan masyarakat sangat mendalam. Dalam tatanan dimensi sosiologis, kedekatan tersebut dapat ditemui dalam upacara-upacara, salah satunya adalah upacara mekala-kalaan yang menggunakan media sambuk sebagai perlengkapan atau peralatan upacara. Kedekatan relasi sambuk dan masyarakat Bali, tampak pula pada pemahaman tentang karakter biologis sambuk dalam proses pembakaran. Sambuk yang sudah dibakar tidak boleh didiamkan. Jika didiamkan, maka apinya akan mati. Oleh karena itu, dalam menyalakan api pada 
Vol. 3, No. 2, Juli 2019, 49

Available Online at https://ejournal.warmadewa.ac.id/index.php/kulturistik DOI: dx.doi.org/10.22225/kulturistik.3.2.1192

sambuk, sebaiknya diayunkan atau dikipas agar api tetap menyala. Dalam tatanan dimensi ideologis, dipahami bahwa api yang diayunkan atau dikipas, akan membara dan menghasilkan suara, yang dalam istilah Bali dikenal dengan ngerepet. Pemahaman karakter biologis yang terekam melalui pengalaman inderawi kemudian memunculkan metafora BALEMAN SAMBUK. Berikut adalah contoh tuturan tersebut:

LIEP-LIEP BALEMAN SAMBUK, YAN UPIN NGREPET (Simpen, 1993: 12)

'kelihatannya pendiam, tapi kenyataanya tidak seperti itu'

Ungkapan dalam sesonngan 'pepatah' tersebut dipahami: seseorang yang nakal tapi tidak terlihat, tetapi ketika temannya datang untuk memancingnya (kenakalannya), maka ia bisa lebih nakal. Makna metaforis tersebut dialamatkan kepada orang yang pendiam namun berbahaya. Parameter keterhubungan dalam ungkapan ini, yaitu keterhubungan antara karakter alamiah sambuk ngrepet yang diidentifikasi sebagai ranah sumber dipetakan kepada manusia sebagai ranah target. Dalam tatanan dimensi biologis, dipahami bahwa karakter alamiah sambuk ngrepet yang ketika diayunkan atau dikipaskan, maka api yang terdapat pada sambuk akan semakin membara. Begitu pula dengan manusia yang memiliki sifat diam-diam berbahaya tersebut. Jika ada kesempatan, maka jati dirinya akan terlihat. Jenis metafora konseptual dalam ungkapan tersebut adalah metafora struktural, yaitu adanya kesamaan sifat atau karakteristik sambuk yang dibakar kemudian diayunkan yang dipetakan dengan sifat seseorang yang dipancing amarahnya, kemudian menjadi-jadi. Jika dilihat dari maknanya, sesonggan dalam ungkapan ini similar dengan pepatah 'air tenang menghanyutkan' dalam bahasa Indonesia.

\section{SIMPULAN}

Makna metaforis yang ditemukan dalam penelitian ini bervariasi, dengan kata lain, proses kognitif dalam membentuk sebuah ungkapan metaforis, yaitu dengan mengonseptualisasi pengalaman yang dirasakan oleh tubuh, sifat, ciri, fungsi, dan kekuatan antara ranah sumber dan ranah target untuk menggambarkan kejadian yang dialami dan dirasakan oleh masyarakat tutur bahasa Bali. Dari hasil penelitian ditemukan bahwa leksikon flora yang merupakan ranah sumber dari metafora merupakan flora yang berada di sekitar lingkungan alam desa atau kota, baik yang dipelihara, dibudidayakan, maupun yang hidup liar di suatu lingkungan. Kesamaan ciri yang berupa bentuk dari ranah sumber dapat dianalogikan dan dibuktikan secara visual, sedangkan keadaan, sifat, dan karakter biologisnya dapat dibuktikan melalui pengalaman tubuh (bodily experience) atau pengalaman empiris masyarakat.

Proses pemetaan silang melalui parameter ekolinguistik (diversity, environment, dan Interrelation, interaction, and interdependency) membuat terbentuknya metafora yang terdapat dalam bahasa Bali. Karakter biologis antara ranah sumber dan ranah target menyebabkan adanya proses pemetaan silang dalam ungkapan metaforis bahasa Bali antara masyarakat dengan flora yang terkonsep secara verbal, dan seterusnya terpola dalam tataran dimensi logis (ideologis, biologis, dan sosiologis). 


\section{DAFTAR PUSTAKA}

Deignan, A. (2005). Metaphor and Corpus Linguisitcs. Amsterdam: John Benjamins Publishing Company.

Lakoff, G., \& Johnson, M. (1980). Metaphors We Live By. Chicago: Chicago University Press.

Mbete, A. M. (2006). Khazanah Budaya Lio- Ende. Ende: Pustaka Larasan.

Moeliono, A. M. (1989). "Diksi atau Pilihan Kata" dalam Kembara Bahasa Kumpulan Karangan Tersebar. Jakarta: Gramedia.

Nazir, M. (1988). Metode Penelitian. Jakarta: Ghalia Indonesia.

Nirmala, D. (2012). Fungsi Pragmatik Metafora dalam Wacana Surat Pembaca Berbahasa Indonesia. LITERA, 11(1).

Rajistha, I. G. N. A. (2016). Beblabadan Bahasa Bali dalam Perspektif Ekolinguistik. RETORIKA: Jurnal Ilmu Bahasa, 2(1), 79-94.

Rasna, I. W. (2012). Kearifan Ekologi Lokal dalam Konservasi Keanekaragaman Leksikal Tanaman Obat Tradisional Bali: Sebuah Kajian Ekolinguistik. Orasi Pengenalan Jabatan Guru Besar Tetap Dalam Bidang Linguistik Pada Fakultas Bahasa Dan Seni Undiksha.

Sewamara. (1977). Kasusastraan Bali (Satua Bawak Mabasa Bali). Singaraja: Balai Penelitian Singaraja.

Simpen, W. A. (1993). Basita Parihasa. Denpasar: Upada Sastra.

Suweta, I. M. (2013). Revitalisasi Istilah Tumbuh-tumbuhan Langka dalam Pengajaran Bahasa Bali, sebagai Upaya Pelestarian Lingkungan Hidup (Kajian Ekolinguistik)". Jurnal Bumi Lestari, 13(1). 